\title{
Single crystal growth and characterization of $\mathrm{Na}_{\mathrm{x}} \mathrm{Ln}_{1-\mathrm{x}} \mathrm{MoO}_{4}, \mathrm{Ln}=\mathrm{La}$,
} Ce, Pr, Nd, Sm, and Eu (x = $0.397-0.499)$

Anthony J. Cortese, Dileka Abeysinghe, Mark D. Smith, Hans-Conrad zur Loye*

Department of Chemistry and Biochemistry, University of South Carolina, Columbia, SC 29208

Corresponding Author: *Email: zurloye@mailbox.sc.edu

RECEIVED DATE (to be automatically inserted after your manuscript is accepted if required according to the journal that you are submitting your paper to)

\begin{abstract}
Single crystals of $\mathrm{La}_{0.516(3)} \mathrm{Na}_{0.484(3)} \mathrm{MoO}_{4}, \mathrm{Ce}_{0.512(2)} \mathrm{Na}_{0.488(2)} \mathrm{MoO}_{4}, \mathrm{Pr}_{0.502(2)} \mathrm{Na}_{0.498(2)} \mathrm{MoO}_{4}$, $\mathrm{Nd}_{0.501(2)} \mathrm{Na}_{0.499(2)} \mathrm{MoO}_{4}, \mathrm{Sm}_{0.509(2)} \mathrm{Na}_{0.491(2)} \mathrm{MoO}_{4}$, and $\mathrm{Eu}_{0.603(2)} \mathrm{Na}_{0.397(2)} \mathrm{MoO}_{4}$ were grown for the first time out of an alkali metal halide eutectic flux. All compounds crystallize in the tetragonal space group $I 4_{1} / a$. UV/Vis measurements show the presence of an absorption edge for all compounds except $\mathrm{Eu}_{0.603(2)} \mathrm{Na}_{0.397(2)} \mathrm{MoO}_{4}$. The temperature dependence of the magnetic susceptibility was measured for all compounds and found to be paramagnetic across the entire 2 - $300 \mathrm{~K}$ temperature range measured.
\end{abstract}

Keywords: molybdenum(V), metal reducing agent, in situ reduction, magnetism, crystal growth 


\section{Introduction}

Crystal growth of compounds containing early transition metals in reduced oxidation states is an emerging area of materials chemistry that has historically been hampered due to the unique synthetic challenges involved in this type of crystal growth. It is, however, an interesting area of research for the creation of oxides containing unpaired electrons, in particular since early transition metals in reduced oxidation states can potentially lead to interesting electrical and magnetic properties. Historically, researchers have reported simple reduced early transition metal oxides such as $\mathrm{VO}_{2}, \mathrm{~V}_{2} \mathrm{O}_{3}[1-3]$, $\mathrm{TiO}[4]$, and $\mathrm{Ti}_{2} \mathrm{O}_{3}[5]$, as well as some ternary and higher reduced oxides, including reduced perovskites and bronzes: $\mathrm{SrTiO}_{2.5}[6], \mathrm{Ba}_{6} \mathrm{Nb}_{14} \mathrm{Si}_{4} \mathrm{O}_{47}[7]$, $A x \mathrm{NbO}_{3}(A=\mathrm{Sr}, \mathrm{Ba})[8,9], \mathrm{Ba}_{3} M_{5} \mathrm{O}_{15}(M=\mathrm{Nb}, \mathrm{Ta})[10,11] A_{0.3} \mathrm{MoO}_{3}(A=\mathrm{K}, \mathrm{Rb}, \mathrm{Tl})[12,13]$, $\mathrm{Cs}_{0.33} \mathrm{MoO}_{3}[14], \mathrm{K}_{2} \mathrm{Mo}_{4} \mathrm{Nb}_{3} \mathrm{O}_{20}$ [15], and $\mathrm{SrV}_{4} \mathrm{O}_{9}$ [16] using crystal growth approaches that include fused salt electrolysis, chemical vapor transport, hydrothermal, and flux methods.

The limited number of known oxides containing reduced early transition metals has pushed us to pursue synthetic strategies to prepare such oxides and to explore their physical properties, including magnetism. One approach, a two step-hydrothermal method, has been very successful for preparing single crystals of hybrid materials containing $\mathrm{V}^{4+}$ and $\mathrm{U}^{4+}[17-23]$. To explore the preparation of reduced oxides, we explored the use of flux crystal growth, a wellknown, facile method for the crystal growth of a diverse oxides, including reduced ones[24]. In order to successfully grow reduced oxide crystals, we carefully selected alkali metal halides as redox neutral fluxes, which can be utilized as high temperature fluxes in sealed reaction vessels, making them excellent candidates for our work. Most compounds reported in the literature were prepared using niobium, tantalum or fused silica sealed tubes[10,25-30]. 
Our approach is based on the in situ reduction of early transition metal cations using a metal reductant, such as Mo, $\mathrm{W}, \mathrm{V}$, or Zn combined with eutectic alkali halide melts in an evacuated sealed fused silica tube. This method has been used by us very successfully for the preparation of reduced oxides containing $\mathrm{Nb}^{4+}, \mathrm{Mo}^{4+}, \mathrm{Mo}^{5+}, \mathrm{V}^{3+}, \mathrm{V}^{4+}$, and $\mathrm{Eu}^{2+}[31-36]$.

Recently we reported the synthesis and characterization of several potassium doped europium molybdates containing $\mathrm{Mo}^{5+/ 6+}$ and $\mathrm{Eu}^{2+/ 3+}$ [32]. In order to fully explore the phase space of these structures we attempted to prepare sodium doped molybdates using analogous reaction conditions, which has resulted in the six title compounds: $\mathrm{La}_{0.516(3)} \mathrm{Na}_{0.484(3)} \mathrm{MoO}_{4}$, $\mathrm{Ce}_{0.512(2)} \mathrm{Na}_{0.488(2)} \mathrm{MoO}_{4}, \mathrm{Pr}_{0.502(2)} \mathrm{Na}_{0.498(2)} \mathrm{MoO}_{4}, \mathrm{Nd}_{0.50} \mathrm{Na}_{0.50} \mathrm{MoO}_{4}, \mathrm{Sm}_{0.509(2)} \mathrm{Na}_{0.491(2)} \mathrm{MoO}_{4}$, and $\mathrm{Eu}_{0.603(2)} \mathrm{Na}_{0.397(2)} \mathrm{MoO}_{4}$. All six compositions crystallize in the scheelite structure $\left(\mathrm{CaWO}{ }_{4} / \mathrm{ABO}_{4}\right)$, which consists of corner sharing 8-coordinate $A$ and 4-coordinate $B$ sites. To the best of our knowledge there do not appear to be any other systems that contain a $\mathrm{MoO} 4$ unit with mixed valance Mo. Mixed valance molybdates such as molybdenum bronzes, however, are widely studied due to their interesting structural and physical properties: superconductivity, metal-semiconductor transition driven by charge density wave state, and quasi-one/twodimensional metallic systems $[13,37,38]$.

To characterize the structure and the oxidation states of the metals within the flux grown single crystals, a combination of single crystal X-ray diffraction, bond valence sum calculations and magnetic susceptibility measurements were employed. Herein, we report the synthesis, crystal structure and physical property characterization $\mathrm{La}_{0.516(3)} \mathrm{Na}_{0.484(3)} \mathrm{MoO}_{4}$, $\mathrm{Ce}_{0.512(2)} \mathrm{Na}_{0.488(2)} \mathrm{MoO}_{4}, \mathrm{Pr}_{0.502(2)} \mathrm{Na}_{0.498(2)} \mathrm{MoO}_{4}, \mathrm{Nd}_{0.501(2)} \mathrm{Na}_{0.499(2)} \mathrm{MoO}_{4}, \mathrm{Sm}_{0.509(2)} \mathrm{Na}_{0.491(2)} \mathrm{MoO}_{4}$, and $\mathrm{Eu}_{0.603(2)} \mathrm{Na}_{0.397(2)} \mathrm{MoO}_{4}$. 


\section{Experimental details}

\section{$2.1 \quad$ Reagents}

$\mathrm{MoO}_{3}$ (99.95\%, Alfa Aesar), Mo metal (99.9\%, 250 mesh, Alfa Aesar) and $\mathrm{CeO}_{2}$ (99.99\%, Alfa Aesar) were used as received. $\mathrm{NaCl}$ (ACS grade, Fisher) and CsCl (99.9\%, Alfa Aesar) were dried prior to synthesis for 24 hours at $260{ }^{\circ} \mathrm{C}$ in an oven. $\mathrm{La}_{2} \mathrm{O}_{3}(99.99 \%$, Alfa Aesar), $\mathrm{Nd}_{2} \mathrm{O}_{3}$ (99.99\%, Alfa Aesar), $\mathrm{Sm}_{2} \mathrm{O}_{3}$ (99.99\%, Alfa Aesar), and $\mathrm{Eu}_{2} \mathrm{O}_{3}$ (99.99\%, Alfa Aesar) were activated at $100{ }^{\circ} \mathrm{C}$ for 12 hours in a furnace before use. $\operatorname{Pr}_{6} \mathrm{O}_{11}$ (Alfa Aesar, 99.9\%) was reduced to $\mathrm{Pr}_{2} \mathrm{O}_{3}$ under $4 \% \mathrm{H}_{2} / 96 \% \mathrm{~N}_{2}$ at $800{ }^{\circ} \mathrm{C}$ for 12 hours before use.

\subsection{Synthesis}

Single crystals of the title compounds were grown in vacuum sealed fused silica tubes out of a $\mathrm{NaCl} / \mathrm{CsCl}$ eutectic melt. As detailed in Table 1, the respective amounts of reagents were placed in a fused silica tube, evacuated to a pressure of $\sim 10^{-4}$ torr, and flame sealed. The title compounds were obtained by heating the mixture at a rate of $10^{\circ} \mathrm{C} / \mathrm{min}$ to a temperature of 825 ${ }^{\circ} \mathrm{C}$, dwelling for 24 hours and cooling the mixture to $450{ }^{\circ} \mathrm{C}$ at a rate of $6{ }^{\circ} \mathrm{C} / \mathrm{hr}$. Single crystals were isolated via vacuum filtration by dissolving the remaining flux in water aided by gentle sonication. As shown in Figure S1, the powder X-ray diffraction patterns (PXRD) of the ground crystals match the patterns calculated using the single crystal structural data.

\subsection{Energy-dispersive spectroscopy (EDS)}

Elemental analysis was performed on all reported single crystals using a TESCAN Vega3 SBU scanning electron microscope (SEM) with EDS capabilities. The crystals were mounted on carbon tape and analyzed using a $20 \mathrm{kV}$ accelerating voltage and an accumulation time of 1 minute. As a qualitative measure, EDS confirmed the presence of each reported element in the title compounds. 


\subsection{Single crystal X-ray diffraction (SXRD)}

X-ray intensity data from crystals of title compounds were collected at 296(2) K using a Bruker SMART APEX diffractometer (Mo K $\alpha$ radiation, $\lambda=0.71073 \AA$ )[39]. The data collection covered $100 \%$ of reciprocal space to $2 \theta_{\max } 65.1-75.6^{\circ}$, with an average reflection redundancy of $5.6-13.4$ and $R_{\mathrm{int}}=0.0179-0.0377$ after absorption correction. The raw area detector data frames were reduced and corrected for absorption effects with the SAINT+ and SADABS programs[39]. Final unit cell parameters were determined by least-squares refinement of 298 444 independent reflections from the data sets. Atomic coordinates of the common $\mathrm{CaWO}_{4}$ structure type were used as an initial structural model. Subsequent difference Fourier calculations and full-matrix least-squares refinement against $F^{2}$ were performed with SHELXL2013/4[40] using the ShelXle interface[41].

All title compounds crystallize in the tetragonal system. The space group $I 4_{1} / a$ (No. 88, origin choice 2) was determined uniquely by the pattern of systematic absences in the intensity data. The compound adopts the scheelite $\left(\mathrm{CaWO}_{4}\right)$ structure type. The asymmetric unit consists of three atomic positions: one mixed $L n /$ Na position (site $4 b,-4$. site symmetry), one Mo atom (site $4 a$, -4. site symmetry) and one oxygen atom (general position, site 16f). The $4 b$ site is occupied by a mixture of $L n$ and Na based on trial refinements. The total site occupancy of the mixed $L n / \mathrm{Na}$ site was constrained to sum to unity. The atomic ratio refined to $L n / \mathrm{Na}=$ 0.516(3)/0.484(3) for La, 0.512(2)/0.488(2) for Ce, 0.502(2)/0.498(2) for Pr, 0.501(2)/0.499(2) for Nd, 0.509(2)/0.491(2) for Sm, and 0.603(2)/0.397(2), for Eu. All atoms were refined with anisotropic displacement parameters. No significant deviation from unity occupancy was observed for the Mo or O atoms. Final atomic coordinates were standardized with Structure 
Tidy[42-44]. Crystallographic data, atomic coordinates and isotropic displacement parameters, and selected interatomic distances are listed in Tables $2-4$.

\subsection{Powder X-ay diffraction (PXRD)}

Powder X-ray diffraction data were collected on either a Rigaku D/Max-2100 or an Ultima(IV) powder X-ray diffractometer using $\mathrm{Cu} \mathrm{K} \alpha$ radiation. The step-scan covered the angular range $5-65^{\circ} 2 \theta$ in steps of $0.04^{\circ}$. The calculated and experimental PXRD patterns are in excellent agreement (see Supporting information, Figure S2).

2.6 UV-vis diffuse reflectance spectroscopy (UV/Vis)

UV-vis diffuse reflectance spectroscopy data of the powder samples of the reported materials were obtained using a Perkin-Elmer Lambda 35 UV-vis scanning spectrophotometer equipped with an integrating sphere in the range of $200-900 \mathrm{~nm}$.

\subsection{Magnetic susceptibility}

The magnetic susceptibility of the reported materials was measured using a Quantum Design MPMS SQUID magnetometer. The zero-field cooled magnetic susceptibility was measured as a function of temperature between 2 and $300 \mathrm{~K}$ in an applied field of 1000 Oe. The measured magnetic moment was corrected for shape and radial offset effects using the methods reported by Morrison et al.[45], which determines the correction factors by comparing the moments observed from DC and VSM scans at a single temperature, $30 \mathrm{~K}$.

\section{Results and discussion}

\subsection{Synthesis}

The flux technique was employed to synthesize the bipyramidal single crystals of the title compounds. Although the flux technique is widely utilized for crystal growth, not all fluxes are 
appropriate for the synthesis of reduced oxides because many of them do not facilitate the necessary redox neutral environment required at elevated reaction temperatures where crystal growth takes place. Alkali metal chlorides, which are redox neutral and known to dissolve a wide variety of elements, can be used for this purpose. $\mathrm{A} \mathrm{NaCl} / \mathrm{CsCl}$ eutectic flux was used to ensure a long liquid range, lower the melting point of the flux, and functions as a source or sodium ions during the crystallization process. By selecting $\mathrm{CsCl}$, we could reasonably expect to exclude the exceptionally large cesium cations from being incorporated into the product crystals while still lowering the melting point of the flux. Reactions using a $\mathrm{NaCl} / \mathrm{KCl}$ eutectic resulted in multiple unidentified phases being present in the product. Mo powder was used as the reducing agent in an attempt to reduce $\mathrm{Mo}(\mathrm{VI})$ to $\mathrm{Mo}(\mathrm{V})$ in situ. This approach worked well for $\mathrm{Eu}_{0.603(2)} \mathrm{Na}_{0.397(2)} \mathrm{MoO}_{4}$, but was less effective for the remaining title compounds. However, in the case of $\mathrm{Ce}_{0.512(2)} \mathrm{Na}_{0.488(2)} \mathrm{MoO}_{4}$, the Mo powder did prove to be an effective reducing agent for the reduction of $\mathrm{Ce}(\mathrm{IV})$ in $\mathrm{CeO}_{2}$ to $\mathrm{Ce}(\mathrm{III})$ in the product crystal. Interestingly, in the case of $\mathrm{Eu}_{0.603(2)} \mathrm{Na}_{0.397(2)} \mathrm{MoO}_{4}$, the Mo powder did not reduce $\mathrm{Eu}(\mathrm{III})$ from $\mathrm{Eu}_{2} \mathrm{O}_{3}$ to $\mathrm{Eu}(\mathrm{II})$ in the product crystal. All products formed in yields approximately between $65 \%$ - and $80 \%$ based on $L n_{2} \mathrm{O}_{3}$ or $\mathrm{CeO}_{2}$.

\subsection{Structure}

The title compounds crystallize in the tetragonal space group $I 4_{1} / a$ adopting the scheelite $\left(\mathrm{CaWO}_{4}\right)$ structure and they exhibit a three dimensional structure consisting of $\mathrm{MoO}_{4}$ tetrahedra and $\mathrm{Na} / \mathrm{LnO}_{8}$ polyhedra. A representation of the three-dimensional structure along the $a$ - axis is shown in Figure 1. Each $\mathrm{Na} / \mathrm{LnO}_{8}$ polyhedron corner shares with eight adjacent $\mathrm{MoO}_{4}$ polyhedra. Mo atoms are located in regular tetrahedra with $\mathrm{Mo}(1)$ - O bond distances ranging from 1.7709 $\AA-1.7746 \AA$. The eight coordinate Na/Ln cations form a distorted eight coordinate polyhedron 
with $\mathrm{Na} / \mathrm{Ln}$ - O bond distances ranging from $2.466 \AA-2.561 \AA$. Bond valance sum $[46,47]$ (BVS) calculations, assuming Mo(VI), for Mo in each compound were found to be 5.77 for $\mathrm{La}_{0.516(3)} \mathrm{Na}_{0.484(3)} \mathrm{MoO}_{4}, 5.74$ for $\mathrm{Ce}_{0.512(2)} \mathrm{Na}_{0.488(2)} \mathrm{MoO}_{4}, 5.76$ for $\operatorname{Pr}_{0.502(2)} \mathrm{Na}_{0.498(2)} \mathrm{MoO}_{4}, 5.72$ for $\mathrm{Nd}_{0.501(2)} \mathrm{Na}_{0.499(2)} \mathrm{MoO}_{4}, 5.73$ for $\mathrm{Sm}_{0.509(2)} \mathrm{Na}_{0.491(2)} \mathrm{MoO}_{4}$, and 5.78 for $\mathrm{Eu}_{0.603(2)} \mathrm{Na}_{0.397(2)} \mathrm{MoO}_{4}$. These sums are consistent with the reported compositions.

\subsection{UV-vis diffuse reflectance spectroscopy (UV/Vis)}

The UV-vis diffuse reflectance data were collected on ground crystals of the title compounds and were converted to absorbance via the Kubelka-Munk function and are shown in Figure 2. The data for $\mathrm{La}_{0.516(3)} \mathrm{Na}_{0.484(3)} \mathrm{MoO}_{4}, \mathrm{Ce}_{0.512(2)} \mathrm{Na}_{0.488(2)} \mathrm{MoO}_{4}, \operatorname{Pr}_{0.502(2)} \mathrm{Na}_{0.498(2)} \mathrm{MoO}_{4}$, $\mathrm{Nd}_{0.501(2)} \mathrm{Na}_{0.499(2)} \mathrm{MoO}_{4}$, and $\mathrm{Sm}_{0.509(2)} \mathrm{Na}_{0.491(2)} \mathrm{MoO}_{4}$, show strong absorption edges clustered approximately around $3.5 \mathrm{eV}$, indicating insulating behavior, which is expected since the concentration of $\mathrm{Mo}(\mathrm{V})$ cations is dilute. For $\mathrm{Nd}_{0.501(2)} \mathrm{Na}_{0.499(2)} \mathrm{MoO}_{4}$ characteristic $f$ - $f$ transitions are observed between $550-900 \mathrm{~nm}$.

\subsection{Magnetic susceptibility}

Unpaired $d$ electrons from $\mathrm{MoO}_{4}$ units and unpaired $f$ electrons from the lanthanide cations are expected to contribute to the magnetic moment of the compounds and can be observed in magnetic susceptibility measurements. The temperature dependence of the magnetic susceptibilities of $\mathrm{La}_{0.516(3)} \mathrm{Na}_{0.484(3)} \mathrm{MoO}_{4}, \mathrm{Ce}_{0.512(2)} \mathrm{Na}_{0.488(2)} \mathrm{MoO}_{4}, \mathrm{Pr}_{0.502(2)} \mathrm{Na}_{0.498(2)} \mathrm{MoO}_{4}$, $\mathrm{Nd}_{0.501(2)} \mathrm{Na}_{0.499(2)} \mathrm{MoO}_{4}, \mathrm{Sm}_{0.509(2)} \mathrm{Na}_{0.491(2)} \mathrm{MoO}_{4}$, and $\mathrm{Eu}_{0.603(2)} \mathrm{Na}_{0.397(2)} \mathrm{MoO}_{4}$ were measured in an applied field of 1000 Oe and are shown in Figure 3. As the amount of $\mathrm{Mo}^{5+}$ is very small for all compounds, no magnetic coupling is expected or observed for molybdenum. The ratios of $\mathrm{Mo}^{5+}$ to $\mathrm{Mo}^{6+}$ are listed in Table 5 . As the lanthanide sites are spatially far apart, no magnetic 
coupling is expected or observed. Down to $2 \mathrm{~K}$, for each compound, the data do not reveal any long range magnetic order. Above $150 \mathrm{~K}$ the data for $\mathrm{La}_{0.516(3)} \mathrm{Na}_{0.484(3)} \mathrm{MoO}_{4}$, $\mathrm{Ce}_{0.512(2)} \mathrm{Na}_{0.488(2)} \mathrm{MoO}_{4}, \mathrm{Pr}_{0.502(2)} \mathrm{Na}_{0.498(2)} \mathrm{MoO}_{4}$, and $\mathrm{Nd}_{0.501(2)} \mathrm{Na}_{0.499(2)} \mathrm{MoO}_{4}$ follow the CurrieWeiss (C-W) law and experimental magnetic moments can be determined. The theoretical and experimental magnetic moments for $\mathrm{La}_{0.516(3)} \mathrm{Na}_{0.484(3)} \mathrm{MoO}_{4}, \mathrm{Ce}_{0.512(2)} \mathrm{Na}_{0.488(2)} \mathrm{MoO}_{4}$, $\operatorname{Pr}_{0.502(2)} \mathrm{Na}_{0.498(2)} \mathrm{MoO}_{4}$, and $\mathrm{Nd}_{0.501(2)} \mathrm{Na}_{0.499(2)} \mathrm{MoO}_{4}$ are collected in Table 5 and are in good agreement. It is well known that samples containing $\mathrm{Sm}^{3+}$ and $\mathrm{Eu}^{3+}$ do not follow the C-W law[48], and hence, to determine the experimental magnetic moment of $\mathrm{Sm}_{0.509(2)} \mathrm{Na}_{0.491(2)} \mathrm{MoO}_{4}$ and $\mathrm{Eu}_{0.603(2)} \mathrm{Na}_{0.397(2)} \mathrm{MoO}_{4}, \chi \mathrm{T}$ vs $\mathrm{T}$ plots were prepared and are shown in Figure 3. The magnetic moments of $\mathrm{Sm}_{0.509(2)} \mathrm{Na}_{0.491(2)} \mathrm{MoO}_{4}$ and $\mathrm{Eu}_{0.603(2)} \mathrm{Na}_{0.397(2)} \mathrm{MoO}_{4}$ at $300 \mathrm{~K}$ are in good agreement with the theoretical $300 \mathrm{~K}$ values and are listed in Table 5.

\section{Conclusion}

We successfully synthesized $\mathrm{La}_{0.516(3)} \mathrm{Na}_{0.484(3)} \mathrm{MoO}_{4}, \mathrm{Ce}_{0.512(2)} \mathrm{Na}_{0.488(2)} \mathrm{MoO}_{4}$, $\mathrm{Pr}_{0.502(2)} \mathrm{Na}_{0.498(2)} \mathrm{MoO}_{4}, \mathrm{Nd}_{0.501(2)} \mathrm{Na}_{0.499(2)} \mathrm{MoO}_{4}, \mathrm{Sm}_{0.509(2)} \mathrm{Na}_{0.491(2)} \mathrm{MoO}_{4}$, and $\mathrm{Eu}_{0.603(2)} \mathrm{Na}_{0.397(2)} \mathrm{MoO}_{4}$. Mo powder was found to be an effective reducing agent in the case of $\mathrm{Ce}_{0.512(2)} \mathrm{Na}_{0.488(2)} \mathrm{MoO}_{4}$, reducing $\mathrm{Ce}(\mathrm{IV})$ to $\mathrm{Ce}(\mathrm{III})$ and in the case of $\mathrm{Eu}_{0.603(2)} \mathrm{Na}_{0.397(2)} \mathrm{MoO}_{4}$, reducing $\mathrm{Mo}(\mathrm{VI})$ to $\mathrm{Mo}(\mathrm{V})$. As a result of the diluteness of the $\mathrm{Mo}^{5+}$ in the title compounds, only simple paramagnetic behavior is observed. The agreement of the experimental and theoretical magnetic moments confirms the stoichiometric ratio of $\mathrm{Na} / \mathrm{Ln}$ in the title compounds.

\section{Acknowledgement}

Financial support for this work was provided by the National Science Foundation under DMR1301757 and is gratefully acknowledged. 
Table 1. Respective amounts of reagents and flux used in each reaction and their respective products obtained with crystal morphologies.

\begin{tabular}{|c|c|c|c|c|}
\hline $\begin{array}{l}\text { Reagents } \\
\text { (mmol) }\end{array}$ & $\begin{array}{l}\text { Reducing agent } \\
\text { (mmol) }\end{array}$ & $\begin{array}{l}\text { Flux } \\
\text { (g) }\end{array}$ & Product & $\begin{array}{l}\text { Crystal Color } \\
\text { and } \\
\text { Morphology }\end{array}$ \\
\hline $\mathrm{MoO}_{3}: \mathrm{La}_{2} \mathrm{O}_{3}$ & Mo & CsCl: $\mathrm{NaCl}$ & \multirow{2}{*}{$\mathrm{La}_{0.516(3)} \mathrm{Na}_{0.484(3)} \mathrm{MoO}_{4}$} & \multirow{2}{*}{$\begin{array}{l}\text { black tetragonal } \\
\text { bipyramids }\end{array}$} \\
\hline $2: 1$ & 0.5 & $2.25: 0.5$ & & \\
\hline $\mathrm{MoO}_{3}: \mathrm{CeO}_{2}$ & Mo & $\mathrm{CsCl}: \mathrm{NaCl}$ & \multirow{2}{*}{$\mathrm{Ce}_{0.512(2)} \mathrm{Na}_{0.488(2)} \mathrm{MoO}_{4}$} & \multirow{2}{*}{$\begin{array}{l}\text { black tetragonal } \\
\text { bipyramids }\end{array}$} \\
\hline $2: 1$ & 0.5 & $2.25: 0.5$ & & \\
\hline $\mathrm{MoO}_{3}: \mathrm{Pr}_{2} \mathrm{O}_{3}$ & Mo & CsCl:NaCl & \multirow{2}{*}{$\mathrm{Pr}_{0.502(2)} \mathrm{Na}_{0.498(2)} \mathrm{MoO}_{4}$} & \multirow{2}{*}{$\begin{array}{l}\text { transparent grey } \\
\text { tetragonal } \\
\text { bipyramids }\end{array}$} \\
\hline $2: 1$ & 0.5 & $2.25: 0.5$ & & \\
\hline $\mathrm{MoO}_{3}: \mathrm{Nd}_{2} \mathrm{O}_{3}$ & Mo & CsCl: $\mathrm{NaCl}$ & \multirow{2}{*}{$\mathrm{Nd}_{0.501(2)} \mathrm{Na}_{0.499(2)} \mathrm{MoO}_{4}$} & \multirow{2}{*}{$\begin{array}{l}\text { transparent purple } \\
\text { tetragonal } \\
\text { bipyramids }\end{array}$} \\
\hline $2: 1$ & 0.5 & $2.25: 0.5$ & & \\
\hline $\mathrm{MoO}_{3}: \mathrm{Sm}_{2} \mathrm{O}_{3}$ & Mo & CsCl: $\mathrm{NaCl}$ & \multirow{2}{*}{$\mathrm{Sm}_{0.509(2)} \mathrm{Na}_{0.491(2)} \mathrm{MoO}_{4}$} & \multirow{2}{*}{$\begin{array}{l}\text { black tetragonal } \\
\text { bipyramids }\end{array}$} \\
\hline $2: 1$ & 0.5 & $2.25: 0.5$ & & \\
\hline $\mathrm{MoO}_{3}: \mathrm{Eu}_{2} \mathrm{O}_{3}$ & Mo & CsCl: $\mathrm{NaCl}$ & \multirow{2}{*}{$\mathrm{Eu}_{0.603(2)} \mathrm{Na}_{0.397(2)} \mathrm{MoO}_{4}$} & \multirow{2}{*}{$\begin{array}{l}\text { black tetragonal } \\
\text { bipyramids }\end{array}$} \\
\hline $2: 1$ & 0.5 & $2.25: 0.5$ & & \\
\hline
\end{tabular}

Table 2. Crystallographic data for $\mathrm{La}_{0.516(3)} \mathrm{Na}_{0.484(3)} \mathrm{MoO}_{4}, \mathrm{Ce}_{0.512(2)} \mathrm{Na}_{0.488(2)} \mathrm{MoO}_{4}$, $\mathrm{Pr}_{0.502(2)} \mathrm{Na}_{0.498(2)} \mathrm{MoO}_{4}, \mathrm{Nd}_{0.501(2)} \mathrm{Na}_{0.499(2)} \mathrm{MoO}_{4}, \mathrm{Sm}_{0.509(2)} \mathrm{Na}_{0.491(2)} \mathrm{MoO}_{4}$, and

$\mathrm{Eu}_{0.603(2)} \mathrm{Na}_{0.397(2)} \mathrm{MoO}_{4}$. Temperature: 296(2) K, crystal system: tetragonal, space group $\mathrm{I}_{1} / a$, and $Z=4$.

\begin{tabular}{|l|c|c|c|}
\hline Formula & $\mathrm{La}_{0.516(3)} \mathrm{Na}_{0.484(3)} \mathrm{MoO}_{4}$ & $\mathrm{Ce}_{0.512(2)} \mathrm{Na}_{0.488(2)} \mathrm{MoO}_{4}$ & $\mathrm{Pr}_{0.502(2)} \mathrm{Na}_{0.498(2)} \mathrm{MoO}_{4}$ \\
\hline Formula weight & 242.74 & 242.90 & 242.07 \\
\hline$a(\AA)$ & $5.3414(2)$ & $5.3173(2)$ & $5.30090(15)$ \\
\hline$c(\AA)$ & $11.7393(6)$ & $11.6652(6)$ & $11.6089(7)$ \\
\hline Volume $\left(\AA^{3}\right)$ & $334.93(3)$ & $329.82(3)$ & $326.20(3)$ \\
\hline Density $\left(\mathrm{g} / \mathrm{cm}^{3}\right)$ & 4.814 & 4.892 & 4.929 \\
\hline Abs. coeff. $\left(\mathrm{mm}^{-1}\right)$ & 10.214 & 10.757 & 11.227 \\
\hline Crystal size $\left(\mathrm{mm}^{3}\right)$ & $0.10 \times 0.08 \times 0.05$ & $0.08 \times 0.06 \times 0.05$ & $0.07 \times 0.05 \times 0.04$ \\
\hline$\theta^{\circ}$ range & $4.192-32.565$ & $4.212-37.802$ & $4.226-35.015$ \\
\hline Reflections collected & 4161 & 5910 & 2053 \\
\hline Completeness to $\theta_{\max }$ & 100.0 & 100.0 & 100.0 \\
\hline$R_{(\text {int })}$ & 0.0179 & 0.0377 & 0.0253 \\
\hline $\mathrm{GOF}\left(F^{2}\right)$ & 1.396 & 1.224 & 0.0195 \\
\hline$R(F)^{a}$ & 0.0271 & 0.0222 & 0.0491 \\
\hline$R_{w}\left(F_{0}{ }^{2}\right)^{b}$ & 0.0434 & 0.0439 & \\
\hline${ }^{a} R(F)=\Sigma\left\|F_{o}|-| F_{c}\right\| / \Sigma\left|F_{o}\right|$ & & \\
\hline${ }^{b} R_{w}\left(F_{o}{ }^{2}\right)=\left[\Sigma w\left(F_{o}{ }^{2}-F_{c}{ }^{2}\right)^{2} / \Sigma w\left(F_{o}{ }^{2}\right)^{1 / 2}\right.$ & & \\
\hline
\end{tabular}


Table 2 (cont.). Crystallographic data for $\mathrm{La}_{0.516(3)} \mathrm{Na}_{0.484(3)} \mathrm{MoO}_{4}, \mathrm{Ce}_{0.512(2)} \mathrm{Na}_{0.488(2)} \mathrm{MoO}_{4}$, $\mathrm{Pr}_{0.502(2)} \mathrm{Na}_{0.498(2)} \mathrm{MoO}_{4}, \mathrm{Nd}_{0.501(2)} \mathrm{Na}_{0.499(2)} \mathrm{MoO}_{4}, \mathrm{Sm}_{0.509(2)} \mathrm{Na}_{0.491(2)} \mathrm{MoO}_{4}$, and

$\mathrm{Eu}_{0.603(2)} \mathrm{Na}_{0.397(2)} \mathrm{MoO}_{4}$. Temperature: 296(2) K, crystal system: tetragonal, space group $\mathrm{I}_{1} / a$, and $Z=4$.

\begin{tabular}{|l|c|c|c|}
\hline Formula & $\mathrm{Nd}_{0.501(2)} \mathrm{Na}_{0.499(2)} \mathrm{MoO}_{4}$ & $\mathrm{Sm}_{0.509(2)} \mathrm{Na}_{0.491(2)} \mathrm{MoO}_{4}$ & $\mathrm{Eu}_{0.603(2)} \mathrm{Na}_{0.397(2)} \mathrm{MoO}_{4}$ \\
\hline Formula weight & 243.68 & 247.79 & 260.67 \\
\hline$a(\AA)$ & $5.2854(2)$ & $5.2560(2)$ & $5.2797(2)$ \\
\hline$c(\AA)$ & $11.5675(6)$ & $11.4921(6)$ & $11.5869(7)$ \\
\hline Volume $\left(\AA^{3}\right)$ & $323.14(3)$ & $317.48(3)$ & $322.99(3)$ \\
\hline Density $\left(\mathrm{g} / \mathrm{cm}^{3}\right)$ & 5.009 & 5.184 & 5.361 \\
\hline Abs. coeff. $\left(\mathrm{mm}^{-1}\right)$ & 11.822 & 13.255 & 15.429 \\
\hline Crystal size $\left(\mathrm{mm}^{3}\right)$ & $0.10 \times 0.08 \times 0.05$ & $0.10 \times 0.08 \times 0.07$ & $0.08 \times 0.06 \times 0.06$ \\
\hline$\theta^{\circ}$ range & $4.239-35.040$ & $4.264-35.106$ & $4.242-32.604$ \\
\hline Reflections collected & 4184 & 4133 & 3773 \\
\hline Completeness to $\theta_{\max }$ & 100.0 & 100.0 & 100.0 \\
\hline$R_{(\text {int })}$ & 0.0260 & 0.0247 & 1.158 \\
\hline $\mathrm{GOF}\left(F^{2}\right)$ & 1.118 & 1.212 & 0.0161 \\
\hline$R(F)^{a}$ & 0.0185 & 0.0252 & 0.0334 \\
\hline$R_{w}\left(F_{0}{ }^{2}\right)^{b}$ & 0.0474 & 0.0664 & \\
\hline${ }^{a} R(F)=\Sigma\left\|F_{o}|-| F_{c}\right\| / \Sigma\left|F_{o}\right|$ & & \\
\hline${ }^{b} R_{w}\left(F_{o}{ }^{2}\right)=\left[\Sigma w\left(F_{o}{ }^{2}-F_{c}{ }^{2}\right)^{2} / \Sigma w\left(F_{o}{ }^{2}\right)^{1 / 2}\right.$ & & \\
\hline
\end{tabular}

Table 3. Selected interatomic distances $(\AA)$ for $\mathrm{La}_{0.516(3)} \mathrm{Na}_{0.484(3)} \mathrm{MoO}_{4}, \mathrm{Ce}_{0.512(2)} \mathrm{Na}_{0.488(2)} \mathrm{MoO}_{4}$, $\mathrm{Pr}_{0.502(2)} \mathrm{Na}_{0.498(2)} \mathrm{MoO}_{4}, \mathrm{Nd}_{0.501(2)} \mathrm{Na}_{0.499(2)} \mathrm{MoO}_{4}, \mathrm{Sm}_{0.509(2)} \mathrm{Na}_{0.491(2)} \mathrm{MoO}_{4}$, and $\mathrm{Eu}_{0.603(2)} \mathrm{Na}_{0.397(2)} \mathrm{MoO}_{4}$.

\begin{tabular}{|c|c|c|c|c|c|}
\hline \multicolumn{5}{|c|}{$\mathrm{La}_{0.516(3)} \mathrm{Na}_{0.484(3)} \mathrm{MoO}_{4}$} \\
\hline $\mathrm{La}(1)-\mathrm{O}(1) \times 4$ & $2.525(2)$ & $\mathrm{La}(1)-\mathrm{O}(1) \times 4$ & $2.561(2)$ & $\mathrm{Mo}(1)-\mathrm{O}(1) \times 4$ & $1.771(2)$ \\
\hline \multicolumn{5}{|c|}{$\mathrm{Ce}_{0.512(2)} \mathrm{Na}_{0.488(2)} \mathrm{MoO}_{4}$} \\
\hline $\mathrm{Ce}(1)-\mathrm{O}(1) \times 4$ & $2.5058(14)$ & $\mathrm{Ce}(1)-\mathrm{O}(1) \times 4$ & $2.5419(14)$ & $\mathrm{Mo}(1)-\mathrm{O}(1) \times 4$ & $1.7729(14)$ \\
\hline \multicolumn{7}{|c|}{$\mathrm{Pr}_{0.502(2)} \mathrm{Na}_{0.498(2)} \mathrm{MoO}_{4}$} \\
\hline $\mathrm{Pr}(1)-\mathrm{O}(1) \times 4$ & $2.4943(15)$ & $\mathrm{Pr}(1)-\mathrm{O}(1) \times 4$ & $2.5288(15)$ & $\mathrm{Mo}(1)-\mathrm{O}(1) \times 4$ & $1.7722(15)$ \\
\hline \multicolumn{7}{|c|}{$\mathrm{Nd}_{0.501(2)} \mathrm{Na}_{0.499(2)} \mathrm{MoO}_{4}$} \\
\hline $\mathrm{Nd}(1)-\mathrm{O}(1) \times 4$ & $2.4842(13)$ & $\mathrm{Nd}(1)-\mathrm{O}(1) \times 4$ & $2.5146(13)$ & $\mathrm{Mo}(1)-\mathrm{O}(1) \times 4$ & $1.7746(13)$ \\
\hline \multicolumn{7}{|c|}{$\mathrm{Sm}_{0.509(2)} \mathrm{Na}_{0.491(2)} \mathrm{MoO}_{4}$} \\
\hline $\mathrm{Sm}(1)-\mathrm{O}(1) \times 4$ & $2.4664(15)$ & $\mathrm{Sm}(1)-\mathrm{O}(1) \times 4$ & $2.4909(15)$ & $\mathrm{Mo}(1)-\mathrm{O}(1) \times 4$ & $1.7742(14)$ \\
\hline \multicolumn{7}{|c|}{$\mathrm{Eu}_{0.603(2)} \mathrm{Na}_{0.397(2)} \mathrm{MoO}_{4}$} \\
\hline $\mathrm{Eu}(1)-\mathrm{O}(1) \times 4$ & $2.4905(17)$ & $\mathrm{Eu}(1)-\mathrm{O}(1) \times 4$ & $2.5108(16)$ & $\mathrm{Mo}(1)-\mathrm{O}(1) \times 4$ & $1.7709(16)$ \\
\hline
\end{tabular}


Table 4. Atomic coordinates and isotropic displacement parameters $\left(\AA^{2} \times 10^{3}\right)$ for $\mathrm{La}_{0.516(3)} \mathrm{Na}_{0.484(3)} \mathrm{MoO}_{4}, \mathrm{Ce}_{0.512(2)} \mathrm{Na}_{0.488(2)} \mathrm{MoO}_{4}, \mathrm{Pr}_{0.502(2)} \mathrm{Na}_{0.498(2)} \mathrm{MoO}_{4}, \mathrm{Nd}_{0.501(2)} \mathrm{Na}_{0.499(2)} \mathrm{MoO}_{4}$, $\mathrm{Sm}_{0.509(2)} \mathrm{Na}_{0.491(2)} \mathrm{MoO}_{4}$, and $\mathrm{Eu}_{0.603(2)} \mathrm{Na}_{0.397(2)} \mathrm{MoO}_{4}$.

\begin{tabular}{|l|l|l|l|l|l|}
\hline $\mathrm{La}_{0.516(3)} \mathrm{Na}_{0.484(3)} \mathrm{MoO}_{4}$ & Occupancy & $x$ & $y$ & $z$ & $\mathrm{U}_{(\mathrm{eq})}$ \\
\hline $\mathrm{La}(1)$ & $0.516(3)$ & 0 & $1 / 4$ & 0.6250 & $12(1)$ \\
\hline $\mathrm{Na}(1)$ & $0.484(3)$ & 0 & $1 / 4$ & 0.6250 & $12(1)$ \\
\hline $\mathrm{Mo}(1)$ & 1 & 0 & $1 / 4$ & 0.6250 & $10(1)$ \\
\hline $\mathrm{O}(1)$ & 1 & $0.2388(4)$ & $0.1087(4)$ & $0.0424(2)$ & $15(1)$ \\
\hline
\end{tabular}

\begin{tabular}{|l|l|l|l|l|l|}
\hline $\mathrm{Ce}_{0.512(2)} \mathrm{Na}_{0.488(2)} \mathrm{MoO}_{4}$ & Occupancy & $x$ & $y$ & $z$ & $\mathrm{U}_{(\mathrm{eq})}$ \\
\hline $\mathrm{Ce}(1)$ & $0.512(2)$ & 0 & $1 / 4$ & 0.6250 & $10(1)$ \\
\hline $\mathrm{Na}(1)$ & $0.488(2)$ & 0 & $1 / 4$ & 0.6250 & $10(1)$ \\
\hline $\mathrm{Mo}(1)$ & 1 & 0 & $1 / 4$ & 0.6250 & $9(1)$ \\
\hline $\mathrm{O}(1)$ & 1 & $0.1427(2)$ & $0.0101(3)$ & $0.2081(1)$ & $15(1)$ \\
\hline
\end{tabular}

\begin{tabular}{|l|l|l|l|l|l|}
\hline $\mathrm{Pr}_{0.502(2)} \mathrm{Na}_{0.498(2)} \mathrm{MoO}_{4}$ & Occupancy & $x$ & $y$ & $z$ & $\mathrm{U}_{(\mathrm{eq})}$ \\
\hline $\mathrm{Pr}(1)$ & $0.502(2)$ & 0 & $1 / 4$ & 0.6250 & $12(1)$ \\
\hline $\mathrm{Na}(1)$ & $0.498(2)$ & 0 & $1 / 4$ & 0.6250 & $12(1)$ \\
\hline $\mathrm{Mo}(1)$ & 1 & 0 & $1 / 4$ & 0.6250 & $12(1)$ \\
\hline $\mathrm{O}(1)$ & 1 & $0.1440(3)$ & $0.0098(3)$ & $0.2084(1)$ & $18(1)$ \\
\hline
\end{tabular}

\begin{tabular}{|l|l|l|l|l|l|}
\hline $\mathrm{Nd}_{0.501(2)} \mathrm{Na}_{0.499(2)} \mathrm{MoO}_{4}$ & Occupancy & $x$ & $y$ & $z$ & $\mathrm{U}_{(\mathrm{eq})}$ \\
\hline $\mathrm{Nd}(1)$ & $0.501(2)$ & 0 & $1 / 4$ & 0.6250 & $11(1)$ \\
\hline $\mathrm{Na}(1)$ & $0.499(2)$ & 0 & $1 / 4$ & 0.6250 & $11(1)$ \\
\hline $\mathrm{Mo}(1)$ & 1 & 0 & $1 / 4$ & 0.1250 & $11(1)$ \\
\hline $\mathrm{O}(1)$ & 1 & $0.2407(2)$ & $0.1043(2)$ & $0.413(1)$ & $18(1)$ \\
\hline
\end{tabular}

\begin{tabular}{|l|l|l|l|l|l|}
\hline $\mathrm{Sm}_{0.509(2)} \mathrm{Na}_{0.491(2)} \mathrm{MoO}_{4}$ & Occupancy & $x$ & $y$ & $z$ & $\mathrm{U}_{(\mathrm{eq})}$ \\
\hline $\mathrm{Sm}(1)$ & $0.509(2)$ & 0 & $1 / 4$ & 0.6250 & $12(1)$ \\
\hline $\mathrm{Na}(1)$ & $0.491(2)$ & 0 & $1 / 4$ & 0.6250 & $12(1)$ \\
\hline $\mathrm{Mo}(1)$ & 1 & 0 & $1 / 4$ & 0.1250 & $12(1)$ \\
\hline $\mathrm{O}(1)$ & 1 & $0.2418(3)$ & $0.1025(3)$ & $0.0410(1)$ & $19(1)$ \\
\hline
\end{tabular}

\begin{tabular}{|l|l|l|l|l|l|}
\hline $\mathrm{Eu}_{0.603(2)} \mathrm{Na}_{0.397(2)} \mathrm{MoO}_{4}$ & Occupancy & $x$ & $y$ & $z$ & $\mathrm{U}_{(\mathrm{eq})}$ \\
\hline $\mathrm{Eu}(1)$ & $0.603(2)$ & 0 & $1 / 4$ & 0.6250 & $12(1)$ \\
\hline $\mathrm{Na}(1)$ & $0.397(2)$ & 0 & $1 / 4$ & 0.6250 & $12(1)$ \\
\hline $\mathrm{Mo}(1)$ & 1 & 0 & $1 / 4$ & 0.1250 & $13(1)$ \\
\hline $\mathrm{O}(1)$ & 1 & $0.1458(2)$ & $0.0095(3)$ & $0.2082(2)$ & $19(1)$ \\
\hline
\end{tabular}


Table 5. Magnetic data for $\mathrm{La}_{0.516(3)} \mathrm{Na}_{0.484(3)} \mathrm{MoO}_{4}, \mathrm{Ce}_{0.512(2)} \mathrm{Na}_{0.488(2)} \mathrm{MoO}_{4}$, $\mathrm{Pr}_{0.502(2)} \mathrm{Na}_{0.498(2)} \mathrm{MoO}_{4}, \mathrm{Nd}_{0.501(2)} \mathrm{Na}_{0.499(2)} \mathrm{MoO}_{4}, \mathrm{Sm}_{0.509(2)} \mathrm{Na}_{0.491(2)} \mathrm{MoO}_{4}$, and $\mathrm{Eu}_{0.603(2)} \mathrm{Na}_{0.397(2)} \mathrm{MoO}_{4}$. For Sm and Eu the calculated moment was taken from a plot of $\chi \mathrm{T}$ as the compound does not obey the C-W law. The ratios of $\mathrm{Mo}^{5+}$ to $\mathrm{Mo}^{6+}$ are also tabulated.

\begin{tabular}{|l|l|l|l|}
\hline Compound & $\mu_{\mathrm{B}}$ theoretical & $\mu_{\mathrm{B}}$ experimental & $\mathrm{Mo}(\mathrm{V}): \mathrm{Mo}(\mathrm{VI})$ \\
\hline $\mathrm{La}_{0.516(3)} \mathrm{Na}_{0.484(3)} \mathrm{MoO}_{4}$ & 0.31 & 0.28 & $0.032: 0.968$ \\
\hline $\mathrm{Ce}_{0.512(2)} \mathrm{Na}_{0.488(2)} \mathrm{MoO}_{4}$ & 1.84 & 1.88 & $0.024: 0.976$ \\
\hline $\mathrm{Pr}_{0.502(2)} \mathrm{Na}_{0.498(2)} \mathrm{MoO}_{4}$ & 2.54 & 2.59 & $0.004: 0.996$ \\
\hline $\mathrm{Nd}_{0.501(2)} \mathrm{Na}_{0.499(2)} \mathrm{MoO}_{4}$ & 2.56 & 2.53 & $0.002: 0.998$ \\
\hline $\mathrm{Sm}_{0.509(2)} \mathrm{Na}_{0.491(2)} \mathrm{MoO}_{4}$ & 1.26 & 1.31 & $0.018: 0.982$ \\
\hline $\mathrm{Eu}_{0.603(2)} \mathrm{Na}_{0.397(2)} \mathrm{MoO}_{4}$ & 2.75 & 2.79 & $0.206: 0.794$ \\
\hline
\end{tabular}


Figure 1 . The 3D structure along the $a$ axis. The $\mathrm{MoO}_{4}$ polyhedra, $\mathrm{Ln} / \mathrm{Na}$ positions, and $\mathrm{O}$ spheres are shown in cyan, orange, and red, respectively. (For interpretation of the references to color in this figure legend, the reader is referred to the web version of this article.)

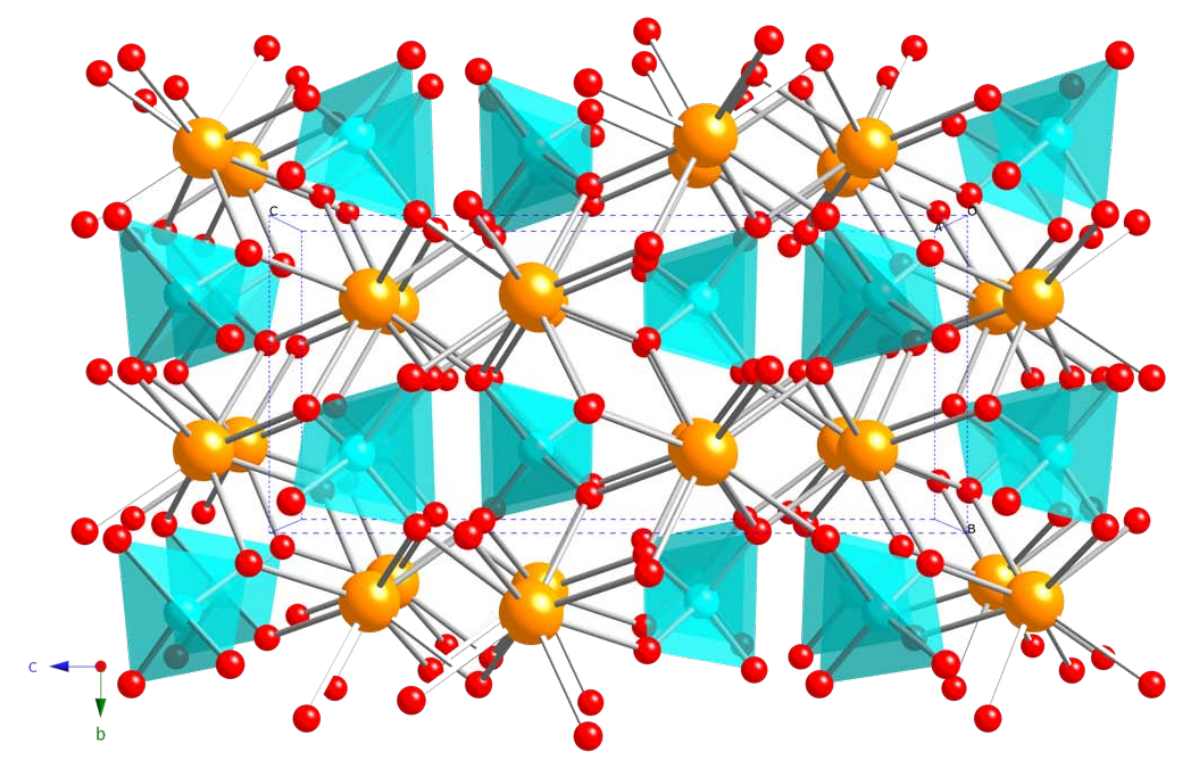


Figure 2. UV-vis diffuse reflectance spectroscopy data for $\mathrm{La}_{0.516(3)} \mathrm{Na}_{0.484(3)} \mathrm{MoO}_{4}$ (cyan), $\mathrm{Ce}_{0.512(2)} \mathrm{Na}_{0.488(2)} \mathrm{MoO}_{4}$ (red), $\mathrm{Pr}_{0.502(2)} \mathrm{Na}_{0.498(2)} \mathrm{MoO}_{4}$ (pink), $\mathrm{Nd}_{0.501(2)} \mathrm{Na}_{0.499(2)} \mathrm{MoO}_{4}$ (black), $\mathrm{Sm}_{0.509(2)} \mathrm{Na}_{0.491(2)} \mathrm{MoO}_{4}$ (blue), and $\mathrm{Eu}_{0.603(2)} \mathrm{Na}_{0.397(2)} \mathrm{MoO}_{4}$ (green).

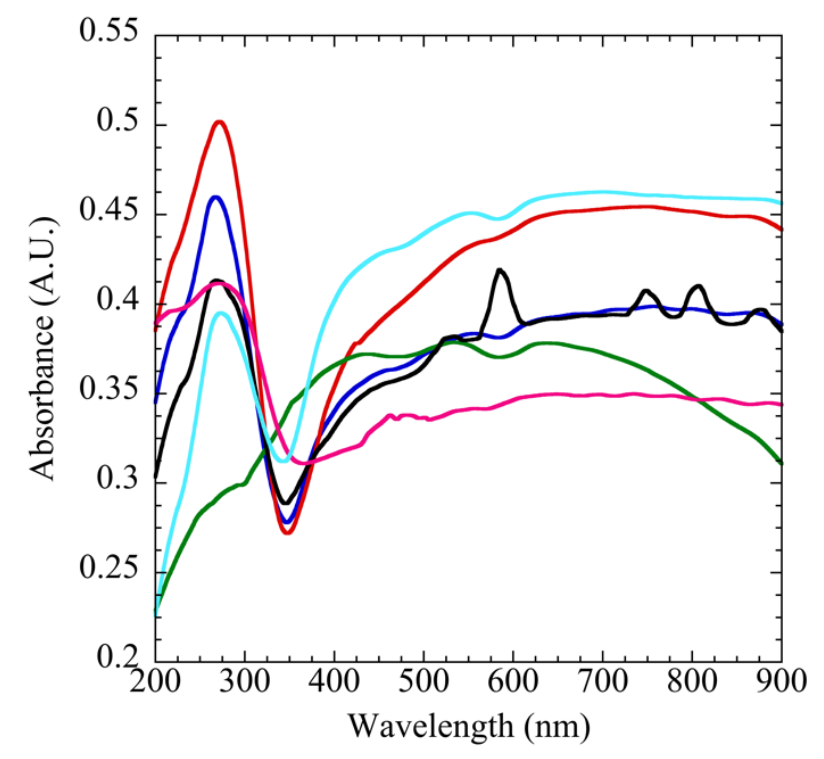

Figure 3. Magnetic susceptibility plots for $\mathrm{La}_{0.516(3)} \mathrm{Na}_{0.484(3)} \mathrm{MoO}_{4}, \mathrm{Ce}_{0.512(2)} \mathrm{Na}_{0.488(2)} \mathrm{MoO}_{4}$, $\mathrm{Pr}_{0.502(2)} \mathrm{Na}_{0.498(2)} \mathrm{MoO}_{4}, \mathrm{Nd}_{0.501(2)} \mathrm{Na}_{0.499(2)} \mathrm{MoO}_{4}, \mathrm{Sm}_{0.509(2)} \mathrm{Na}_{0.491(2)} \mathrm{MoO}_{4}$, and $\mathrm{Eu}_{0.603(2)} \mathrm{Na}_{0.397(2)} \mathrm{MoO}_{4} \cdot \chi$ and $1 / \chi$ are shown in red and blue, respectively. For $\mathrm{Sm}_{0.509(2)} \mathrm{Na}_{0.491(2)} \mathrm{MoO}_{4}$ and $\mathrm{Eu}_{0.603(2)} \mathrm{Na}_{0.397(2)} \mathrm{MoO}_{4}$ a $\chi \mathrm{T}$ plot is shown, as they do not obey the C-W law.

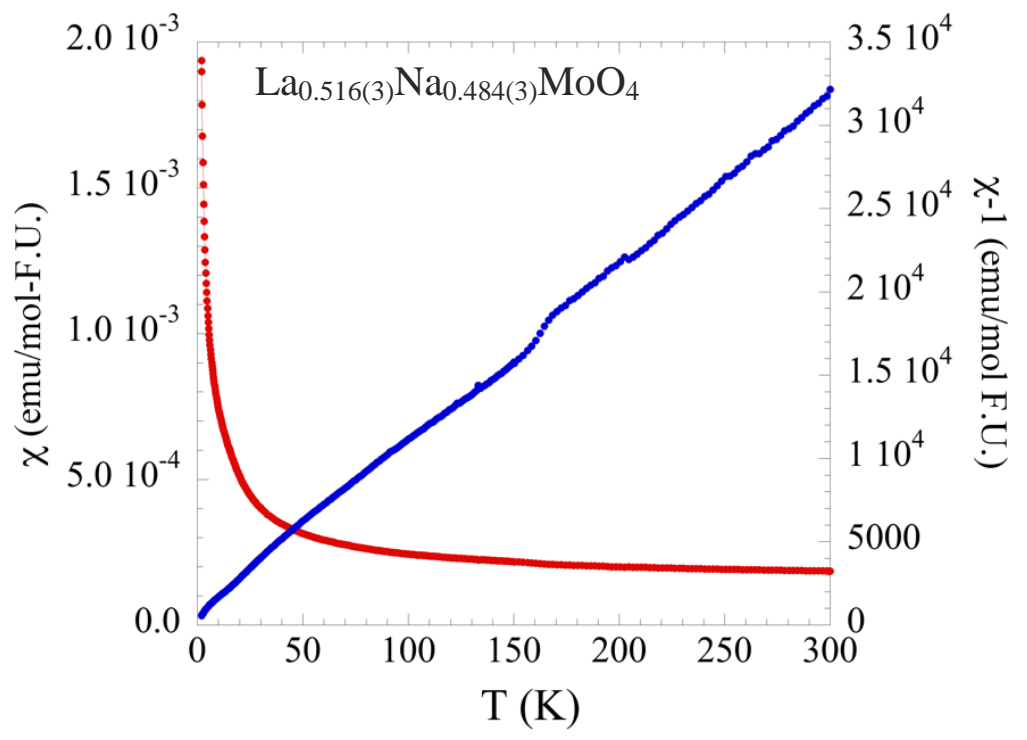



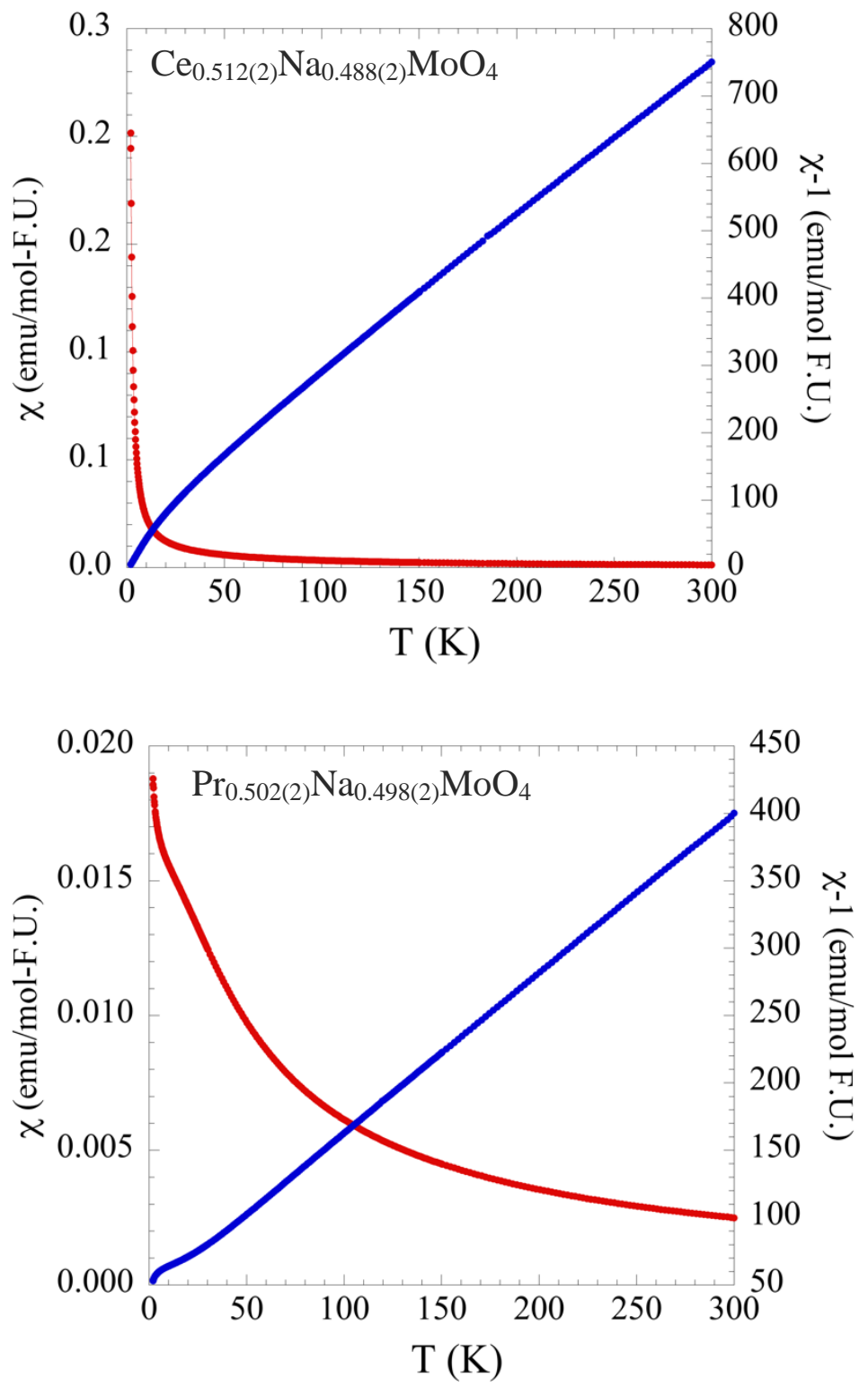

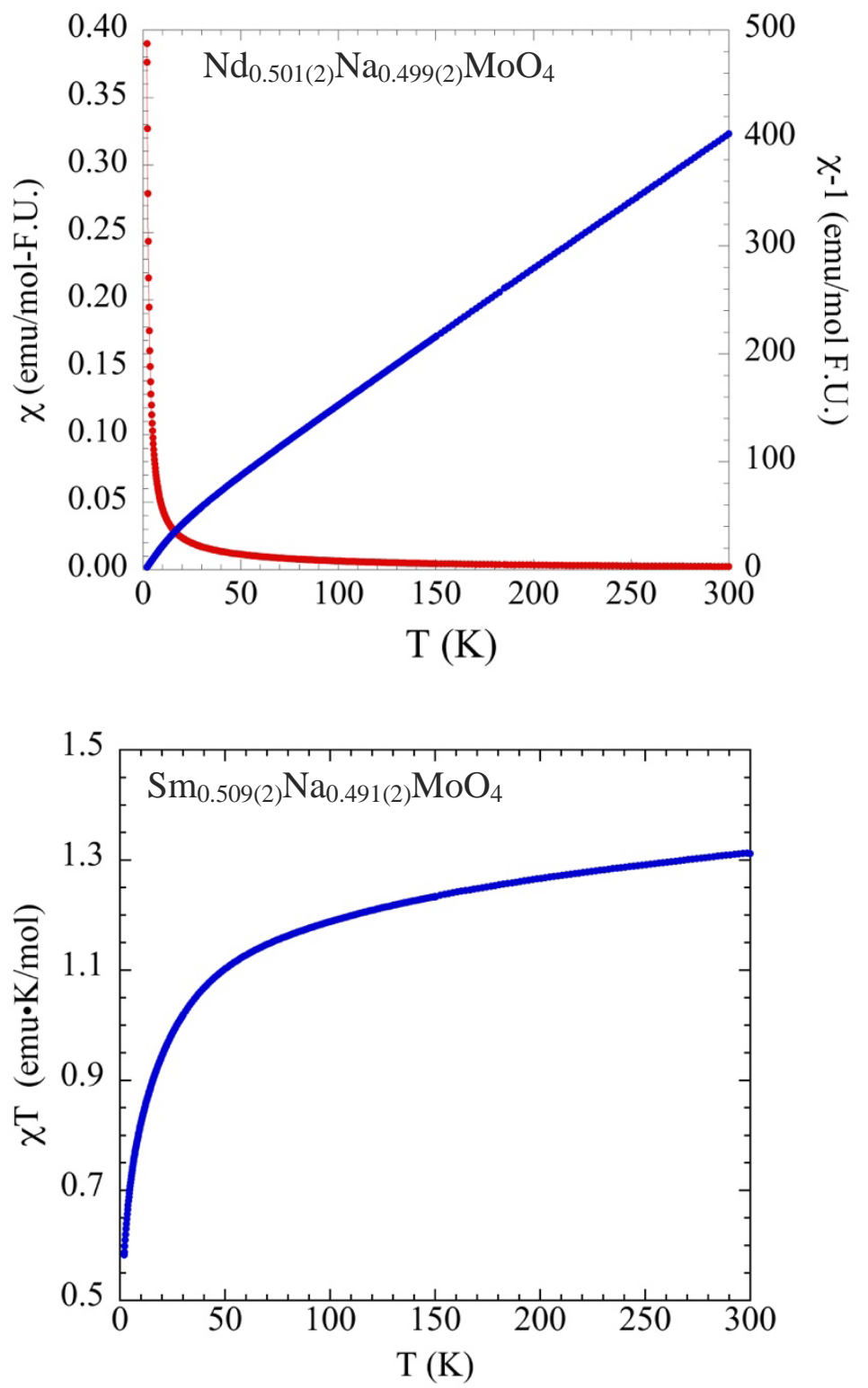


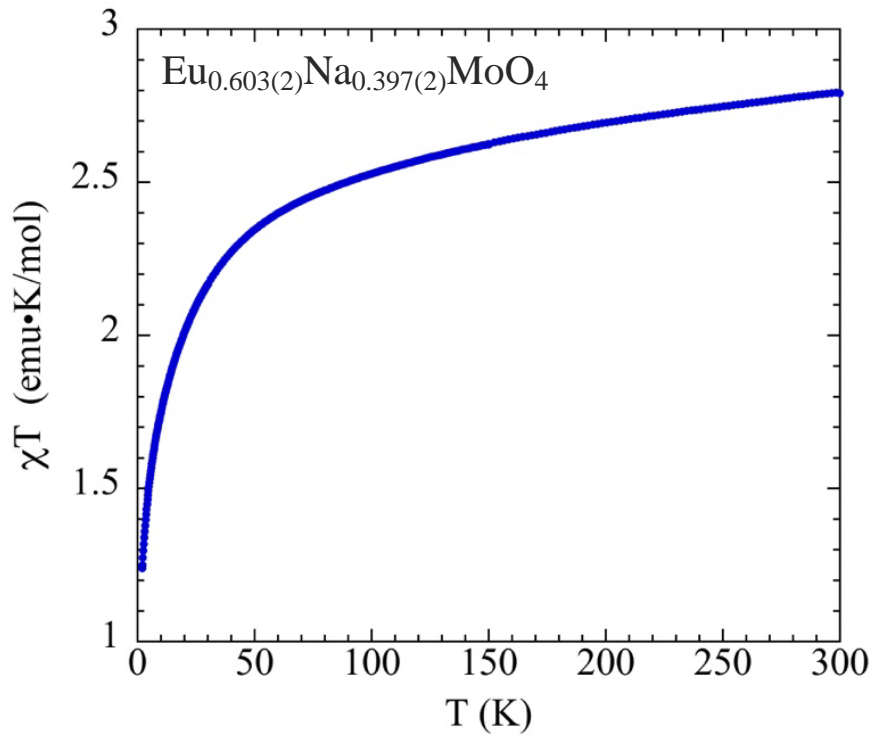




\section{References}

[1] G. Andersson, Acta. Chem. Scand. 8 (1954) 1599-1606.

[2] M. Pouchard, J.C. Launay, Mater. Res. Bull. 8 (1973) 95-104.

[3] S. Westman, C. Nordmark, Acta. Chem. Scand. 14 (1960) 465-470.

[4] F.J. Morin, Bell Syst. Tech. J. 37 (1958) 1047-1084.

[5] L.L.V. Zandt, J.M. Honig, J.B. Goodneough, J. Appl. Phys. 39 (1968) 594-595.

[6] M. Kestigian, J.G. Dickinson, R. Ward, J. Am. Chem. Soc. 79 (1957) 5598-5601.

[7] D.L. Serra, S.-J. Hwu, J. Solid State Chem. 101 (1992) 32-40.

[8] B. Hessen, S.A. Sunshine, T. Siegrist, R. Jimenez, Mater. Res. Bull. 26 (1991) 85-90.

[9] D. Ridgley, R. Ward, J. Am. Chem. Soc. 77 (1955) 6132-6136.

[10] C.R. Feger, R.P. Ziebarth, Chem. Mater. 7 (1995) 373-378.

[11] B. Hessen, S.A. Sunshine, T. Siegrist, A.T. Fiory, J.V. Waszczak, Chem. Mater. 3 (1991) 528-534.

[12] M. Greenblatt, Chem. Rev. 88 (1988) 31-53.

[13] M. Greenblatt, Physics and Chemistry of Materials with Low-Dimensional Structures 11 (1989) 1-48.

[14] P.P. Tsai, J.A. Potenza, M. Greenblatt, J. Solid State Chem. 69 (1987) 329-335.

[15] S.C. Chen, B. Wang, M. Greenblatt, Inorg. Chem. 32 (1993) 4306-4310.

[16] Y. Oka, T. Yao, N. Yamamoto, M. Ueda, S. Maegawa, J. Solid State Chem. 149 (2000) 414-418.

[17] D. Abeysinghe, M.D. Smith, J. Yeon, G. Morrison, H.-C. zur Loye, Cryst. Growth Des. 14 (2014) 4749-4758.

[18] A.J. Cortese, B. Wilkins, M.D. Smith, J. Yeon, G. Morrison, T.T. Tran, P.S. Halasyamani, H.-C. zur Loye, Inorg. Chem. 54 (2015) 4011-4020.

[19] J. Yeon, M.D. Smith, A.S. Sefat, H.-C. zur Loye, Inorg. Chem. 52 (2013) 2199-2207. 
[20] J. Yeon, M.D. Smith, A.S. Sefat, T.T. Tran, P.S. Halasyamani, H.-C. zur Loye, Inorg. Chem. 52 (2013) 8303-8305.

[21] J. Yeon, M.D. Smith, J. Tapp, A. Moller, H.-C. zur Loye, J. Am. Chem. Soc. 136 (2014) 3955-3963.

[22] J. Yeon, A.S. Sefat, T.T. Tran, P.S. Halasyamani, H.-C. zur Loye, Inorg. Chem. 52 (2013) 6179-6186.

[23] J. Yeon, J.B. Felder, M.D. Smith, G. Morrison, H.-C.Z. Loye, CrystEngComm 17 (2015) 8428-8440.

[24] D.E. Bugaris, H.-C. zur Loye, Angew. Chem. Int. Ed. 51 (2012) 3780-3811.

[25] S.J. Clarke, A.J. Fowkes, A. Harrison, R.M. Ibberson, M.J. Rosseinsky, Chem. Mater. 10 (1998) 372-384.

[26] O.G. D’yachenko, S.Y. Istomin, A.M. Abakumov, E.V. Antipov, Inorg. Mater. 36 (2000) 247-259.

[27] M.J. Geselbracht, L.D. Noailles, L.T. Ngo, J.H. Pikul, Chem. Mater. 16 (2004) 1153-1159.

[28] S.Y. Istomin, G. Svensson, O.G. D’yachenko, W. Holm, E.V. Antipov, J. Solid State Chem. 141 (1998) 514-521.

[29] P. Mahjoor, S.E. Latturner, Inorg. Chem. 49 (2010) 4486-4490.

[30] T. Siegrist, R.J. Cava, J.J. Krajewski, Mater. Res. Bull. 32 (1997) 881-887.

[31] A.J. Cortese, D. Abeysinghe, B. Wilkins, M.D. Smith, H.-C. zur Loye, Cryst. Growth Des. (submitted)

[32] D. Abeysinghe, B. Gerke, G. Morrison, C.H. Hsieh, M.D. Smith, R. Pöttgen, T.M. Makris, H.-C. zur Loye, J. Solid State Chem. 229 (2015) 173-180.

[33] A.J. Cortese, D. Abeysinghe, B. Wilkins, M.D. Smith, G. Morrison, H.-C. zur Loye, Inorg. Chem. 54 (2015) 11875-11882.

[34] A.J. Cortese, B. Wilkins, M.D. Smith, G. Morrison, H.-C. zur Loye, Solid State Sci. 48 (2015) 133-140.

[35] A.J. Cortese, B. Wilkins, M.D. Smith, G. Morrison, H.-C. zur Loye, Solid State Sci. 48 (2015) 7-12.

[36] D. Abeysinghe, M.D. Smith, J. Yeon, G. Morrison, H.-C. zur Loye, Inorg. Chem. 55 (2016) 1821-1830. 
[37] M.-H. Whangbo, E. Canadell, J. Am. Chem. Soc. 110 (1988) 358-363.

[38] A.W. Sleight, T.A. Bither, P.E. Bierstedt, Solid State Commun. 7 (1969) 299-300.

[39] SMART Version 5.631, SAINT+ Version 6.45 and SADABS Version 2.10. Bruker Analytical X-ray Systems, Inc., Madison, Wisconsin, USA, 2003.

[40] G.M. Sheldrick, Acta Crystallogr. A 64 (2008) 112-122.

[41] C.B. Hubschle, G.M. Sheldrick, B. Dittrich, J. Appl. Crystallogr. 44 (2011) 1281-1284.

[42] L.M. Gelato, E. Parthe, J. Appl. Crystallogr. 20 (1987) 139-143.

[43] S.Z. Hu, E. Parthe, Chin. J. Struct. Chem. 23 (2004) 1150-1160.

[44] E. Parthe, L.M. Gelato, Acta Crystallogr. A40 (1984) 169-183.

[45] G. Morrison, H.-C. zur Loye, J. Solid State Chem. 221 (2015) 334-337.

[46] N.E. Brese, M. O’Keeffe, Acta Crystallogr. B 47 (1991) 192-197.

[47] I.D. Brown, D. Altermatt, Acta Crystallogr. B 41 (1985) 244-247.

[48] S. Blundell, (2001) Magnetism in Condensed Matter. 


\section{Graphical Abstract}

Single crystals of $\mathrm{La}_{0.516(3)} \mathrm{Na}_{0.484(3)} \mathrm{MoO}_{4}, \mathrm{Ce}_{0.512(2)} \mathrm{Na}_{0.48(2)} \mathrm{MoO}_{4}, \mathrm{Pr}_{0.502(2)} \mathrm{Na}_{0.498(2)} \mathrm{MoO}_{4}$, $\mathrm{Nd}_{0.501(2)} \mathrm{Na}_{0.499(2)} \mathrm{MoO}_{4}, \mathrm{Sm}_{0.509(2)} \mathrm{Na}_{0.491(2)} \mathrm{MoO}_{4}$, and $\mathrm{Eu}_{0.603(2)} \mathrm{Na}_{0.397(2)} \mathrm{MoO}_{4}$ were grown for the first time out of an alkali metal halide eutectic flux. All compounds crystallize in the tetragonal space group $I_{1} / a$. $\mathrm{Eu}_{0.603(2)} \mathrm{Na}_{0.397(2)} \mathrm{MoO}_{4}$ was found to possess the highest $\mathrm{Mo}^{5+}$ content at $20.6 \%$. UV/Vis, magnetic susceptibility, and a bond valence sum analysis were performed on all samples.
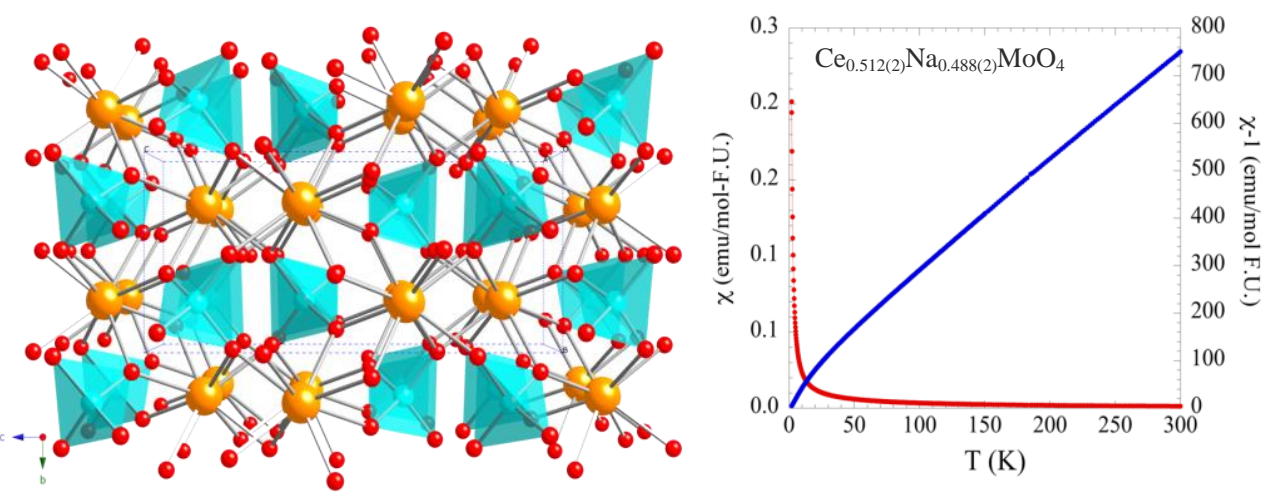